findings. The extremely small size of the chromosomes in most members of the Ulotrichales is probably the reason for the lack of any extensive cytological work on the group.

The materials indicated by an asterisk in the above list were obtained from the Cambridge Culture Collection of Algae and Protozoa. The materials of $M$. amoenc and $U$. zonata were collected from Wise Een 'Tarn and Lake Windermere respectively. Detailed accounts of mitosis in the above forms will be published elsewhere.

Department of Botany, Y. S. R. K. SARMA

Queen Mary College

(University of London), London, E.1. Feb. 14.

'Sarma, Y. S. R. K., Nature, 177, 900 (1956).

2 v. Neuenstein, H., Arch. f. Zellforsch., 13, 1 (1914).

${ }^{3}$ Schussnig, B., Z. Zellforsch., 10, 642 (1930a).

${ }^{4}$ Gross, I., Arch. Protistenk., 73, 206 (1931).

${ }^{5}$ v. Cholnoky, B., Beih. bot. Zbl., 49, 221 (1932a) ; Z. Zellforsch., 16. $707(1932 c)$.

'Lind, E. M., Ann. Bot., 46, 711 (1932).

\section{A Non-Destructive Method of detecting Diseases in Wood}

ULTRASONIC equipment has been used by the Timber Development Association for detecting flaws in wood, and its possible development for determining the presence of diseased tissues has been suggested ${ }^{1}$. The principle of this type of flaw detection is to generate pressure (sound) waves of very high frequency which are transmitted through suspect materials such as metals or plastics. When flaws are present, the reduction of the degree of transmission in the defective area can be measured. Ultrasonic waves produced by commercial flaw detectors do not harm the materials being tested. The equipment is portable.

In these trials transmission of ultrasonic energy through wood was measured both down and across the grain. After two areas, on exactly opposite sides of the samples, had been smoothed to give two flat surfaces, each about $25 \mathrm{sq}$. cm. in area, the wood was smeared with a coupling agent to ensure good contact between the probes and the wood. To transmit across the grain the sampling areas had to be stripped of bark, which was found to be impenetrable to the ultrasonic energies employed.

The transmission of ultrasonic energy through wood is considerably reduced even when slight defects are present (Table 1). The sensitivity could probably be increased with sets specially adapted for detecting flaws in timber. No transmission could be obtained through $5 \mathrm{~cm}$. of red pine infected with dry rot even though ultrasonic energy could be transmitted through $130 \mathrm{~cm}$. of sound seasoned beech.

Besides its potential value as a research tool for studying the ecology of tree disease organisms, the most important development of this technique would be the reduction of economic losses of timber. Trees of value are often lost because fungal infections (such as heart and butt rots) remain undetected for many years. The early detection of disease in a plantation would enable a decision to be made about its potential value and future management. Loss on imports or timber in storage could be reduced if a speedy method of detecting incipient decay in bulk timber were available.

We should like to express our thanks to the Atomic Energy Research Establishment, Harwell, and to Messrs. Kelvin Hughes for permission to use equipment at their laboratories; to Mr. E. Skippen, of A.E.R.E., for his advice and assistance; and to Mr. Abel Ward for allowing us to take samples from Eggerslack, Grange-over-Sands.

\section{J. S. WAID}

Nature Conservancy,

Merlewood Research Station,

Grange-over-Sands, Lancashire.

'Agric., 63, 294 (1956).

\section{Eels in Southern Africa}

Sponsoned by the South African Council for Industrial and Scientific Research, this Department, under the direction of Prof. J. L. B. Smith, is undertaking the study of the life-history of the freshwater eels of the western Indian Ocean. Most authorities have hitherto held that only one species of freshwater eel, namely, Anguilla mossambica Peters, occurs in South Africa. Ege ${ }^{1}$ recorded a specimen of Anguilla

Table 1. Relative Transmission of Ultrasonic Energy throdgh Samples of Wood

\begin{tabular}{|c|c|c|c|c|c|c|c|c|c|c|}
\hline \multirow{4}{*}{$\begin{array}{l}\text { Direction } \\
\text { of trans- } \\
\text { mission }\end{array}$} & \multirow{4}{*}{ Flaw detector } & \multirow{4}{*}{$\begin{array}{l}\text { Fre- } \\
\text { quency } \\
\text { (mega- } \\
\text { cycles) }\end{array}$} & \multirow{4}{*}{ Transducer } & \multirow{4}{*}{$\begin{array}{l}\text { Coupling } \\
\text { agent }\end{array}$} & \multicolumn{6}{|c|}{ Percentage transmission through sound wood* } \\
\hline & & & & & \multicolumn{3}{|c|}{ Birch $\uparrow$} & \multicolumn{3}{|c|}{ Oakt } \\
\hline & & & & & \multirow{2}{*}{$\begin{array}{l}\text { Sound } \\
\text { wood }\end{array}$} & \multicolumn{2}{|c|}{$\begin{array}{l}\text { Wood infected by } \\
\text { Polyporus betulinus }\end{array}$} & \multirow{2}{*}{$\begin{array}{l}\text { Sound } \\
\text { wood }\end{array}$} & \multirow{2}{*}{$\begin{array}{l}\text { Sound wood } \\
\text { with hole } \frac{1}{2} \text { in. } \\
\text { diameter } \\
\text { drilled } \\
\text { longitudinaliy }\end{array}$} & \multirow{2}{*}{$\begin{array}{c}\text { Brittle } \\
\text { wood with } \\
\text { pockets } \\
\text { of rot }\end{array}$} \\
\hline & & & & & & $\begin{array}{c}\text { Central rot } \\
32 \text { per cent by vol. }\end{array}$ & $\begin{array}{l}\text { Completely } \\
\text { rotten }\end{array}$ & & & \\
\hline \multirow{3}{*}{$\begin{array}{c}\text { Across } \\
\text { grain }\end{array}$} & $\begin{array}{l}\text { Kejvin Hughes } \\
\text { Mark V }\end{array}$ & $\frac{1}{2}$ & Quartz & 'Polycel' & 100 & 0 & 0 & - & - & - \\
\hline & Kelvin Hughes & $\frac{1}{2}$ & Barium & 'Vaseline' & 100 & 20 & 0 & 100 & 10 & 50 \\
\hline & $\begin{array}{c}\text { Kraut Kramer } \\
\text { Mark IX }\end{array}$ & $\frac{1}{6}$ & $\begin{array}{c}\text { Barium } \\
\text { titanate }\end{array}$ & 'Polycel' & 100 & $17-33$ & 0 & 100 & $3-23$ & $12-27$ \\
\hline \multirow{3}{*}{$\begin{array}{c}\text { Down } \\
\text { grain }\end{array}$} & $\begin{array}{l}\text { Kelvin Hughes } \\
\text { Mark V }\end{array}$ & $\frac{1}{2}$ & Quartz & 'Polycel' & 100 & 38 & 0 & - & 一 & - \\
\hline & Kelvin Hughes & $\frac{1}{2}$ & Barium & 'Vaseline' & 100 & 10 & 0 & 100 & - & 15 \\
\hline & $\begin{array}{l}\text { Kraut Kramer } \\
\text { Mark IX }\end{array}$ & 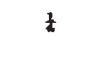 & $\begin{array}{l}\text { Barium } \\
\text { titanate }\end{array}$ & 'Polycel' & - & 一 & - & 100 & 一 & 55 \\
\hline
\end{tabular}

- Absolute values are not shown as machines were not calibrated and scale values recorded were peculiar to each machine, so values obtained

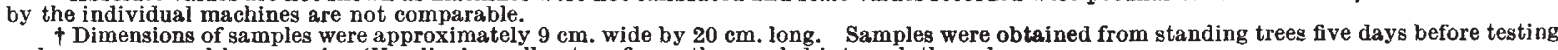

and were preserved by smearing 'Vaseline' on all cut surfaces, then sealed into polythene bags.
$\ddagger$ Machine not tuned, so efticiency was about 5 per cent. 